\title{
Improving Outcomes for Children Affected by Parental Involvement with the Criminal Justice System in Scotland
}

\author{
Tony Long ${ }^{1}$ (]) Kelly Lockwood ${ }^{1}$ (i) $\cdot$ Nancy Loucks $^{2}$ [D $\cdot$ Briege Nugent $^{1}[$. \\ Ben Raikes $^{3}$ (D) Kathryn Sharratt ${ }^{4} \cdot$ - Louise Gallagher ${ }^{5}$ (i)
}

Received: 3 May 2021 / Accepted: 8 October 2021 /Published online: 9 November 2021

(c) The Author(s) 2021

\begin{abstract}
With 20-27,000 children in Scotland experiencing a parent's imprisonment and many more their parent's involvement in the wider criminal justice system, it is vital that children's needs and preferences are understood and acted upon. Parental imprisonment or involvement with the justice system short of imprisonment is a cause of deleterious chronic stress and adverse childhood experience. This 18-month participative study in Scotland was designed to establish the problems of having a parent involved in the criminal justice system and to co-produce solutions with affected families. The experiences of 14 children and young people were elicited through interviews (supplemented with input from parents and professionals), followed by a family consultation event. Schools elicited complex relationships of both stress and threat, an outlet, and a means for positive achievement despite the stressors. Schools need proactively to identify children who are struggling emotionally and to provide sensitive, discreet support. Children felt victimised by authorities and the community, experiencing devastating family disruption and loss of childhood. Community-based interventions could educate others about the impact on children of victimisation. Young people emphasised the need to humanise their experience from point-of-arrest to years after release. They sought more child-friendly prison visiting, physical contact, and meaningful activity with their parent. Parents wanted the development of parent-to-parent and young people-led support groups. A means to signpost affected families to self-support groups is needed. A model of symbiotic harm is used to offer theoretical context to the findings.
\end{abstract}

Keywords Children · Young people $\cdot$ Prison · Parent $\cdot$ Criminal justice system · Resilience symbiotic harm

Tony Long

t.long@salford.ac.uk

Extended author information available on the last page of the article 


\section{Introduction}

The needs and experiences of families of those involved in the criminal justice system has gained increasing visibility in both academia and policy over the last decade (Booth, 2020; Condry \& Minson, 2020; Hutton \& Moran, 2019; Lockwood et al., 2021; Woodall \& Kinsella, 2017). However, the focus of this work has been directed primarily toward the families of those in prison. For example, in England and Wales, increasing policy interest has been directed toward the importance of familial contact during custody and the role of children and families of prisoners in reducing reoffending (Farmer, 2017; HMIP, 2016); with the social capital that they can provide considered vital in supporting effective resettlement (Booth, 2020). The emergent body of academic work has also brought attention to the wide range of negative impacts on those with a family member in prison (Jones \& Wainaina-Wozna, 2013; Lee et al., 2014; Lanskey et al., 2019; Long et al., 2019; McGinley \& Jones, 2018); with a distinct body of work identifying the specific difficulties experienced by children with a parent in prison (Jones \& Wainaina-Wozna, 2013; Phillips et al., 2002; Scottish Centre for Crime and Justice Research, 2019; Woodall \& Kinsella, 2017). Despite this growing body of knowledge, significant gaps remain.

Research in the UK has focused primarily on England and Wales, with the Scottish context less well explored. However, with high levels of social inequality disproportionately distributed within its prison population (McCarthy \& Adams, 2017), specific recognition of the Scottish context is merited as these families are more likely to have multiple disadvantages and complex needs (Phillips \& Erkanli, 2008). Equally, maintaining familial contact during a custodial sentence can be particularly challenging for families in Scotland owing to distance of the prison from their homes (Loucks, 2012). Secondly, whilst knowledge and understanding of the needs of children with a parent in prison continues to develop, less is known of the impact on children with a parent involved in other, or multiple, areas of the criminal justice system. To address these gaps, Condry \& Minson's (2021) concept of 'symbiotic harms' was adopted in a qualitative design to explore the impact of having a parent involved in five different stages of the criminal justice system: arrest, court, probation, prison and resettlement. Whilst bringing attention to the significant challenges experienced by children with a parent involved in the criminal justice system, this study was also designed to raise awareness of the capacity, resilience and resistance of children as they negotiate and make sense of their situation.

\section{Background}

\section{Advances and Gaps in the Evidence Base}

Research examining parental involvement across agencies within the criminal justice system is limited (Bartlett et al., 2018). However, these children are identified 
as being among the most complex cases encountered by child protection agencies (Gifford et al., 2016; Phillips \& Detlaff, 2009). Much of the available research focuses on parental imprisonment with minimal consideration of other, or indeed multiple, points of parental involvement in the criminal justice system.

The limited body of research specifically exploring parental arrest identifies the detrimental impact on children. Research in England (Tilley-Riley, 2016) and the USA (Phillips \& Zhao, 2010) shows that children who witness parental arrest are likely to be traumatised by the incident, and develop strong negative views of the police; experiencing loss of sleep, separation anxiety, hyper-vigilance, irritability, withdrawal, and post-traumatic stress disorder. There is increased risk of problem behaviours, particularly substance misuse, and subsequent arrest (Dallaire \& Wilson, 2010; Phillips \& Zhao, 2010). Findings from Australia and the USA also highlight that parental arrest can be traumatic, bewildering, stressful and confrontational, and often left unexplained to the child (Flynn et al., 2015). It was noted that formal responses to children following parental arrest are chaotic, with competing obligations to police procedures and the duty of care to children. These gaps in provision are equally identified in research in the UK, which calls for enhanced training for the police and the prioritisation of children's welfare by conducting arrests in a constructive and child-centric way (Kincaid et al., 2019; Tilley-Riley, 2016).

Research in the experiences, impact and needs of children during parental criminal court procedures is perhaps the least developed area of criminal justice. Epstein (2011) found that in court processing of mothers with dependent children, the courts did not always refer to the rights of the child when sentencing. More recently, Minson (2021) noted unwillingness of judges to make appropriate enquiries about children and the impact of their mothers' sentence on them. Children can find it particularly challenging when their parent's court case is reported in the media (Beresford et al., 2020). Lockwood \& Raikes (2016) identified the challenges of non-disclosure of arrest, court and potential imprisonment and consequent impact on children when parents do not return home from court. Tilley-Riley (2016) argues that children should be recognised at the earliest opportunity, to enable support to be offered prior to a court hearing and given an opportunity to inform court reports.

Research about children with a parent on a probation order is scarce, and little is known about their needs and experiences (Phillips et al., 2010). Exploring high levels of psychological stress of American mothers supervised by probation order, Rieder et al. (2019) highlighted the links between maternal stress and child behavioural health. Phillips and Zhao (2010) investigated emotional and behavioural problems in probationers' children and their access to services. They identified significant gaps in provision. Although the children had increased likelihood of experiencing problems, they had lower-than-expected likelihood of receiving services. Probation departments needed to be more proactive in linking probationers' children to services.

The complexity of factors has been addressed in the USA and the UK. Children are not a homogenous group, and ongoing developmental stage, family environment and wider social factors influence the impact of parental imprisonment (Dallaire et al., 2010). Families with complex vulnerability experience dynamic processes over time, punctuated by engagement in different aspects of the justice system. Each 
aspect challenges the resilience of the child and family unit. Appropriate support and resources to mitigate such effects requires consideration of the short- and longterm effects of arrest, separation, parental absence during imprisonment, and reunion after release (Parke \& Clarke-Stewart, 2002).

\section{Disadvantage, Stigma and Resilience}

Children of prisoners are more likely than their peers to experience significant disadvantage with multiple, complex needs. They encounter social exclusion, financial difficulties, family discord, instability of care arrangements, stigma, isolation, victimisation, and poor educational attainment in the UK (Ayre et al., 2006; Boswell, 2018; Glover, 2009; Murray, 2007; Murray et al., 2009; Smith et al., 2007); Australia (Flynn et al., 2015); the USA (Crawford, 2003); Denmark (Scharff-Smith \& Gampell, 2011); and Ireland (King, 2002). Evidence from the UK (Boswell, 2018); the USA (Arditti, 2018; Crawford, 2003); Australia (Cunningham, 2001; Halsey, 2018); and The Netherlands (Hissel et al., 2011) suggests significant short-term and enduring emotional difficulties for children and young people, including feelings of grief, loss and sadness, distress, confusion and anger, suffering depression, becoming withdrawn or secretive, showing regressive or attention seeking behaviour, having disturbed sleep patterns, eating disorders, and symptoms of post-traumatic stress disorder.

Parental involvement in the criminal justice system can also lead to children experiencing stigma (Murray et al., 2012). Such stigma can increase teachers' expectations of behavioural problems by up to $40 \%$ (Wildeman et al., 2017). Children who are told the truth about their parents' involvement in the criminal justice system fare better than those "protected" from the truth (Lockwood \& Raikes, 2016). Research in Sweden found that children (mainly girls) coped with parental imprisonment through talking to family and friends, with support from school, by viewing the future positively, and perceiving imprisonment as a transient problem (Steinhoff \& Berman, 2012). With family-friendly prison policies and positive support at school, Swedish children experienced less stigma than those in Germany, Romania or the UK (Jones \& Wainaina-Wozna, 2013). Children can be strong and resourceful with innate capacity to overcome problems and challenges. Lösel et al. (2012) found that children of prisoners supporting younger siblings demonstrated less anxiety than other children. Positive relationships and a capacity for lasting bonds with parent figures are also crucial for better health and wellbeing outcomes (Dodds, 2016; Jones \& Wainaina-Wozna, 2013). Effective interventions for children of prisoners should adopt positive psychology approaches and develop resilience through sustained contact between children and imprisoned parents (Măirean et al., 2012). Conversely, parental imprisonment brings welcome respite for some children from a delinquent or abusive parent (Jones \& Wainaina-Wozna, 2013), while some mothers benefit from their partner's incarceration (Arditti et al., 2003). 


\section{International Policy}

The UN Special Rapporteur for the Human Rights Committee conducted a consultation on children's right to privacy, which has particular application to children with a parent involved with the justice system (UN, 2021). The difficulties associated with using data to ensure support for children of incarcerated parents while preventing unnecessary sharing of personal information beyond those who provide the support was raised. Protection of the privacy of children whose parents are in conflict with the law (particularly in the media), and upholding children's privacy during contact in any form with incarcerated parents (particularly during prison visits) were also highlighted as essential aspects of law and practice.

While not legally enforceable, recommendations by the Council of Europe (2018) are enormously important the application of the United Nations Convention on the Rights of the Child (UNCRC) (UNICEF, 1989) to children with an imprisoned parent. The Council of Europe holds that such children must be treated with respect for their human rights and their individual needs taken into consideration; and they must be offered the opportunity for their views to be heard (especially about decisions that impact on them). They should have the option of frequent and regular prison visits according to their age; and security checks on them should be undertaken in a child-friendly manner, respecting their dignity and psychological integrity. Intrusive searches (notably body cavity searches) should be prohibited. The degree of compliance with these recommendations is varied.

\section{Solutions in Scotland}

An estimated 20-27,000 children in Scotland each year experience the imprisonment of a parent (Scottish Government, 2017; Scottish Government Justice Analytical Services, 2012), with many more affected by parental involvement in the criminal justice system without imprisonment. Non-stigmatising, asset-based treatment models being developed for substance-abusing women are recommended by McGillivray (2016). The Criminal Justice (Scotland) Act 2016 obligated an impact assessment on the occasion of parental imprisonment, though this aspect of the legislation was never implemented. More attention needs to be paid to the experiences of children who have parents involved across the criminal justice system (Phillips \& Detlaff, 2009). These families are often among the most complex cases encountered by child protection agencies (Gifford et al., 2016). However, considerable efforts have been made to improve family-friendly policies in Scottish prisons. Costs of phone calls from people in prison custody have been reduced (Prison Reform Trust, 2013), and the 'E-mail a Prisoner' scheme is now universally available across the UK. The Scottish Prison Service established standards for encouraging family contact in 2013, promoting flexible visiting, improved transport links and advertising the availability of financial support for visits. There are serious attempts to enhance the quality of visits for children, including addressing prison staff attitudes, and to improve release planning by involving families. 
The UNCRC was approved unanimously for incorporation into domestic law in Scotland. This means that issues such as non-discrimination based on the status of one's parent (Art.2); the child's best interest as a primary consideration in decisions that concern them (Art.3); the right to contact with parents (Art.9); the right to have a voice in any decision that affects them directly or indirectly (Art.12); the right to privacy (Art.16); and the right to support when a child cannot be in the care of their parent (Art.20) will all have a basis in legislation and be legally enforceable and challengeable.

\section{Symbiotic Harms Approach}

Addressing gaps in existing approaches that construct the families of prisoners as either 'collateral consequences', or as sites of secondary punishment, Condry and Minson's (2020) 'symbiotic harms' aims to define the negative effects of imprisonment that flow both ways through the interdependencies of intimate associations. Such harms are characterised by their relational, mutual, non-linear, agentic, and heterogeneous properties. Although developed in relation to the harms of imprisonment, this research adds to this body of knowledge by exploring the impact of children in having a parent involved in different aspects of the criminal justice system.

\section{Study Design}

This study was designed with two stages: eliciting the experiences of children and young people through face-to-face interviews (supplemented with interviews with the remaining parent and involved professionals), followed by stakeholder events to facilitate co-production of proposed solutions. The aim was to explore the impact of parental involvement in the justice system on children, young people and their families or significant caregiver, and to co-produce responses to those findings.

\section{Research Objectives}

- To explore with children and young people as active participants the health and social impacts of parental involvement at four points in the justice system

- To co-produce relevant and appropriate responses to the findings that enable resilience-building in the individual in both the family and community setting

- To explore with professionals and service providers their understanding and responses to the families' reports [not reported here].

\section{Research Ethics and Governance}

A risk-management approach was adopted to address ethical issues (Long, 2007). Printed information sheets were available for all participants, including a simple version to be read to young children. These explained involvement in the study, emphasising the voluntary nature of participation and the right to withdraw without 
giving any reason, and providing details of third parties in case of concern. Formal consent forms were offered, but more often audio-recorded verbal consent was provided. Formal approval was secured from the University of Salford Research Ethics Committee (HSR1617-22). Clearly, this was research with a vulnerable group, and particular efforts were made to ensure informed participation. The participant information sheet to be read to young children had a high Flesch Reading Ease Score of 83.3/100 (equivalent to a children's novel, and a little more difficult than comics), and that for adults was 77/100. All participants were aware of their parent's involvement in the justice system, though several had been misled when younger. Interviews were conducted by a female researcher with extensive research experience in the field with similar populations, and children had the option to be interviewed alone (in sight of the parent) or with the parent. Offering the opportunity to be heard to a population of children whose voice is largely unheard was both valued by the participants and vital if services were to be made aware of their problems and preferred solutions (Livesley \& Long, 2012).

\section{Sample}

Experiences of a parent's (1) arrest and charging, (2) serving a custodial sentence, (3) serving a community order or (4) completion of sentence were addressed with children and young people up to 18 years, parents, and professionals within Glasgow City. The target was 40 families within Glasgow City. Direct recruitment was not possible, and agencies had to be approached to identify potential participants (based on inclusion and exclusion criteria) and to seek their agreement to be put in contact with the researchers. Despite varied and sustained recruitment activities including visits to establishments, posters, team briefings, advertisements and word of mouth; multiple research ethics approval applications; apparent willingness by individuals to support the initiative; driving by the commissioning partnership; and contact with over 100 organisations (Table 1), few introductions were made. It is not known if or how many young people were contacted and declined to take part. All who were

Table 1. Organisations approached during recruitment

\begin{tabular}{lll}
\hline Type of organisation & $\begin{array}{l}\text { Number } \\
\text { approached }\end{array}$ & Examples of services \\
\hline National Health Service & 9 & Substance/addiction, parenting team, CAMHS \\
Prison & 7 & Prison, family contact officer, parenting, social work \\
School & 5 & School, family support, psychological support \\
Social Work & 18 & Children/family service, kinship carer, criminal justice team \\
Voluntary Sector & 60 & $\begin{array}{c}\text { Mentoring, family support, mental health, employability, } \\
\text { substance misuse }\end{array}$ \\
Other & 10 & $\begin{array}{c}\text { Community partnership, youth team, legal support, recovery } \\
\text { service, church group, domestic violence }\end{array}$ \\
TOTAL & $\mathbf{1 0 9}$ & \\
\hline
\end{tabular}


introduced to the researchers readily agreed to participate. Extended discussion of this issue is not possible in this report but will be published separately.

Fourteen cases from 10 families were recruited (Table 2). One young adult beyond the planned age range was included on request because of clear memory of the experience and longer-term impact. All were White and Scottish. Three were of primary school age, seven were of secondary school age, and three were 18 years old (Fig. 1). The parents involved in the criminal justice system were three mothers and eleven fathers. One had been arrested, charged, and was awaiting trial; one was serving a community order; nine were serving custodial sentences; and three had been released from custody. These were mostly high-level offences, which could be considered to represent a skewed sample, yet it is unusual to access such cases in research, and this was a remarkable opportunity for learning. Parents participated in twelve cases and professionals in three. Given the study design and lack of control over participant selection, there was no question of generalisability. However, the range of age groups for Scottish educational provision was reflected in the sample - a meaningful categorisation given the concomitant transitions and life events associated with this central aspect of children's lives. There was more representation of children who were old enough to reflect on current and previous experiences, and these may have been more likely to volunteer to express their thoughts.

\section{Data Collection}

\section{Interviews}

Data collection was undertaken in the home or in another preferred place. A raft of age-appropriate methods was available to engage children and young people. This

Table 2. Details of participants

\begin{tabular}{lllll}
\hline Case & Sex & Age & Stage in CJS & Others interviewed \\
\hline 1 & F & 18 & Mother released from prison & Professional \\
2 & F & 11 & Father in custody & Mother \\
3 & M & 16 & Father in custody & Mother \\
4 & M & 10 & Father in custody & Mother \\
5 & F & 8 & Father serving community sentence & Father \\
6 & M & 16 & Father awaiting trial & Father \\
7 & F & 5 & Father released from custody & Father, Professional \\
8 & F & 16 & Mother released from prison & Mother \\
9 & F & 18 & Mother in custody & Professional \\
10 & M & 18 & Father in custody & Mother \\
11 & F & 12 & Father in custody & Mother \\
12 & F & $24 *$ & Father in custody & Mother \\
13 & F & 12 & Father in custody & Mother \\
14 & M & 12 & Father in custody & Mother \\
\hline
\end{tabular}

*Allowed to contribute since she held clear memories and addressed issues of longer-term impacts 


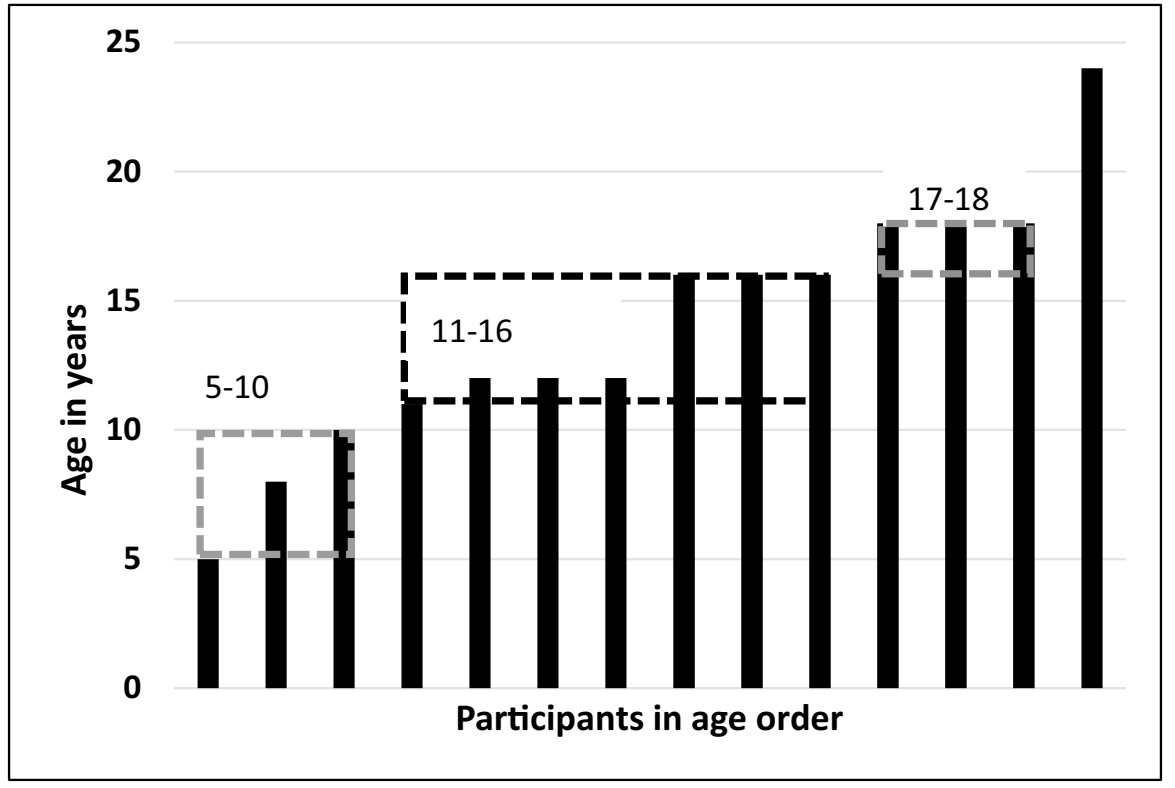

Fig. 1. Participant age groups

mosaic approach (Clarke, 2004) has been used effectively especially with young children (Livesley \& Long, 2012) to facilitate participation of those with limited communication ability and for other reasons. Some young people preferred to be interviewed alone while others (younger children) elected to be interviewed with a parent. The focus was drawn to their experiences, reactions, understanding, support and what carried them through the experience. Consideration of internal (personal strengths and fears), external (effect of friends, family, services), and environmental (co-existing challenges, concurrent life events) factors was encouraged. The interviews were audio-recorded and lasted between 60 and 90 min.

\section{Consultation Events}

Structured, informal discussions with families were led by the research team on issues that had arisen from the interviews and directed towards suggestions for improvements. Participants were able to write thoughts and comments on tablecloths, adding to the contributions of others, and often including pictures and diagrams. This was followed by relaxed, free-ranging and creative discussion in a mobile research laboratory (a large display vehicle designed for taking research to young people, parked in a neutral location, equipped with multiple means of consultation and engagement), led by the families themselves, and observed by the researchers. Although not reported here, an interactive event was held for practitioners from all involved agencies to consider the findings from the families and to contemplate solutions (Fig. 2). This also included attendance by the Children and Young People's Commissioner in Scotland and participation by a family affected 
conserve the intended meaning. There was discussion of selected items, resulting in reallocation to a different part of the framework." Charting" of each completed index or part of the framework was undertaken first by an induvial researcher before being reviewed and amended by the other three. In order to prioritise the evidence from the young people, contributions from professionals were added only at this stage. In the final stage of "mapping" the results were reported, offering data extracts as evidence of valid representation of the contribution and meaning intended by participants. In order to protect participants' confidentiality, no service users were included in the process of data analysis.

\section{Findings}

\section{Multiple Disadvantage and Complex Need}

Consistent with existing research, families often experienced multiple disadvantage, including physical and mental ill-health, domestic violence, substance misuse, physical and sexual abuse, and historic involvement in the criminal justice system.

Mum's got a lot of mental health as well ... she's got personality disorder, anxiety, depression. She'd always had substance abuse problems. She would drink, she'd be violent. She had partners coming in and out of her life all the time, and she would be so aggressive to them. [Case 1: young person, mother released from prison]

He's got anxiety problems. He's got sensory overload. He just cannot cope with too many people around about him. [Case 4, mother about her son, father in custody]

I remember things from when I was a wee lassie, like the domestic violence... how violent and nasty he [father] was. [Case 9: young person, mother in custody]

I was abused. I was raped by my grandfather on a regular basis from the ages of four to ten. [Case 10, mother, father in custody]

Condry \& Minson (2021, p.12) note that the families of those in prison are not 'a monolithic group' and explore the 'mediators and moderators of experiences'. Moderators can exacerbate or alleviate the effects of familial imprisonment. As identified in this study, many families had significant existing disadvantages and complex needs which exacerbated their experiences. Resilience can alleviate the effects of imprisonment (Condry \& Minson, 2021) so holistic, family-centred support that attends to the needs of the whole family is required to build greater resilience.

\section{Changed Lives: Lives on Hold}

Having a parent involved in the criminal justice system brought significant changes to families' daily lives, relationships, roles and responsibilities. 
Childhood was compromised in order for children to support the family. Lives were totally disrupted: with children having to move home, change

Everything's been put on hold. I got my dream job, and because my mental health was deteriorating, I said 'I don't feel as if I' $m$ ready to go back whatsoever until all this is over with my dad and we know what's happening'. He was the whole rock. He held everybody, and with him not being here it's been hellish. It's been absolute torture. [Case 12: young person, father in custody]

I don't really want to celebrate my birthday. It feels awkward. Dad's not here. I've got a feeling that I shouldn't be celebrating without him. [Case 13: child, father in custody]

A common concern was that of changing family roles, with children absorbing parental responsibilities.

We're all serving a sentence too. We've been thrown into a different way of life than what we should have been. Growing up, it was: 'You need to do [sister's] homework with her. You need to teach her this. You need to make an effort'. Sometimes I'm still bitter that I didn't get to be a kid. [Case 10: young person, father in custody]

Relationality is a key perspective in Condry and Minson's (2020) symbiotic harms framework. This perspective acknowledges that kin relationships remain entwined throughout a prison sentence and recognises the significance of relationships to sense of self. This research has highlighted that even when an individual is removed from the family home owing to imprisonment, their presence (even if symbolic) remains significant, with experiences of everyday life and relationships with others mediated through their relationship with their parent in custody.

\section{Secrets, Honesty and Communication}

There was confusion, deceit, honesty and complicity about information relating to the parent's involvement with the criminal justice system. When not told explicitly, children found out by other means (sometimes erroneously) and were careful about who they would confide in. Some families had been honest and made children aware about their parent's involvement in the criminal justice system from the beginning. When honesty had characterised the explanation, this was valued.

People were open for the first time in her life, to be honest. It just made her better. [Case 11: mother, father in custody]

He knows everything. He knows everything from start to finish. [Case 4: mother, father in custody]

I didn't lie, I said 'I am not guilty, so I know the verdict will be honest. So, I don't have any fears'. [Case 8: mother released from prison]

My dad was clear with me when it happened. He would just tell me what happened: the truth. [Case 6: young person, father awaiting trial] 
I came home from school and my big sister said, 'We need to talk' and then we sat down. And she said, 'Your dad's been put into jail'. [Case 14: child, father in custody]

For other families, disclosure was not a choice, and children were made aware owing to media coverage of the case and the nature of the offence.

I was watching the news one night with my carer and my mum's face came up, and I was pure looking at her and I started greeting (crying), and my carer asked why I was greeting, and I said, 'That's my mum', and she was like, 'No, no it's not your mum', and she turned it off. And the next day my social worker came to tell me, 'Your mum's in prison'. [Case 9: young person, mother in custody]

I think it was when I was on the phone with my dad when I was nine, maybe. And it said, 'this call is from a Scottish prison'. And I was just like... 'Mum, is Dad in prison?' [Case 11: child, father in custody]

Some families tried to hide the truth from children, usually with thoughts of protecting them.

He asked all the time, 'Where's my dad?' And it was the usual, 'Oh, he's working away'. It was just lies after lies, but to protect him. It wasn't malicious. [Case 10: mother, father in custody]

You try and shield them from what they don't need to know. [Case 4: mother, father in custody]

I didn't get told anything. I've never been told. I don't get told by the police or anything. [Case 1: young person, mother released from prison]

One young girl, interviewed with her father after his release from prison, continued to believe that she had been visiting him at work during his sentence.

I see him (father) in work every day. He's not in the same work now. [Case 7: child, father released from custody]

Some children knew that their parent was in prison but had never been given any more information or had a conversation about the situation. Prison visiting made concealment of the facts impossible. One young woman whose parent had served two custodial sentences had received no information at all.

I always think it's funny. My mum still tried to lie and keep it from me, and I was showing up to somewhere with a fence and fingerprint scanners and dogs, you know. I think all kids know. [Case 10: young person, father in custody]

I just said to them their daddy was at work, and I took them to the prison. But when we walked in the door it was like, 'Mum, we're in a prison. Why are we in a prison?' So, then it was that conversation had to be said. [Case 4: mother, father in custody]

The problems with failing to be truthful were that children might seek their own answers, arriving at the wrong conclusion, and if the opportunity to discuss their doubts and worries were denied them, then they were left to try to cope alone. Most 
children and young people had no outlet and no-one to trust. They bore the burden in silence.

I don't tell anyone... I just think it's my business. [Case 4: child, father in custody]

I don't talk about it... I didn't tell anybody. It's the best way of dealing with it.

[Case 5: child, father serving community sentence]

Especially in primary school and the start of high school, I wouldn't tell anyone. Close friends knew. But I wouldn't talk about it. [Case 10: young person, father in custody]

The symbiotic harms framework captures the non-linear and messy reality of the experience of familial imprisonment. Whilst Condry and Minson's (2020) framework focuses on the negotiation and renegotiation of kin relationships, this research has also highlighted the messiness of negotiating and renegotiating disclosure and non-disclosure of information relating to parental imprisonment. This was rarely a one-off event or linear process and families had to constantly negotiate when and how much information to share in different situations and contexts. Consistent with Condry and Minson's (2020) framework, this research has also shown the agency of families in making decisions, managing situations, and sharing information in particular ways, to particular people at particular times in order to manage relationships and mediate the implications of disclosure.

\section{Support for the Supporters}

The most vociferously argued issue by parents was the lack of support for those who supported the children and young people affected by having a parent involved in the criminal justice system. Families often felt angry with statutory professionals such as social workers and police officers, and they were reluctant to seek help from them.

I don't want to rely on anybody, because I know what happens. [Case 3: mother, father in custody]

Peer support was described repeatedly as an unexploited resource.

I see women and families at visits. Everybody's feeling the same way: dying for somebody to talk to. Nobody's there. They need somebody who can identify that person, know that she needs help, look her in the eye and say, "I've been where you are, and so have my kids". [Case 10: mother, father in custody]

For some parents the support that they sought related to direct, professional help for their children's needs. Specific services and organisations focused on supporting families of prisoners such as Families Outside were often cited. Their workers were valued because they made no judgements and offered practical support.

Sometimes when she [support worker] comes in I just burst out crying. Just to have that support there and, do you know what, I can tell her anything. [Case 4: mother, father in custody] 
The relational perspective of the symbiotic harms approach can also aid understanding of the impact of imprisonment on relationships within families, beyond those between individual family member and their loved one in prison (such as children and their parent/carer) and the relationship with other key actors who come into their lives, such as peers or NGOs. There was recognition by parents that sometimes children would open up more about their feelings to others beyond the family such as NGO workers or school mentors, and this was one means of offering support for their supporters, too. Families wanted peer-led support by those with the same experience, based on existing strengths of families. A mother at the family event suggested that mindfulness training would be useful to assist parents to remain positive and to be more able to support their children. Carers wanted earlier support from the time of arrest as well as during court proceedings. The significance of those relationships as part of the everyday lives and support networks of families is identified within this research.

\section{School as Support}

Schools could be a place of humiliation. Equally, they could be an escape and a place to achieve in life despite other problems. Children commonly retained aspirations to professional careers. There were examples of discreet, effective support from head teachers and pastoral care, though more commonly the experience was more challenging.

I remember I went into school and everybody already knew without me saying.

The whole school knew. I was the only person in the whole school whose mum was in prison. I stopped going to school. [Case 9: child, mother in custody]

The level of disruption in young people's lives and the consequent impact on school attainment was felt not to be understood by many teachers. This was seen to link to teachers needing to be aware of the problem without unnecessary dissemination of personal information more widely. Young people reported feeling safer with a small group of friends at school. One commented that only his head teacher knew about the issues, and he wanted to keep it that way. He referred to everyone else at the school as 'nosey people' [Case 4: child, father in custody]. Over time, he explained, he had learned how to keep his situation secret at school.

One girl at school in an affluent area reported that the school had failed to recognise the difficulty that she was in. She felt worse as she perceived that she was surrounded by peers who had no such issues in their lives, yet she felt unable to alert the school staff to her problems.

I don't think they have dealt with something like that [parental imprisonment] before so they don't understand. I was breaking down every day and couldn't talk to people. I just secluded myself in a room. Then I'd be seen as a problem. But because I get up every day and I go to school, and I do well in school, and I have hope for the future, they think, 'Oh, she's fine'.

The same teenager went on to report further similar experiences. 
A good few times teachers (would) get me into trouble for the smallest thing and I would literally just burst out in tears and I'd have to leave the class because I couldn't cope with the fact that they were telling me I was doing something wrong at that point. But obviously they didn't understand that it wasn't just that, it was everything else. [Case 1: young person, mother released from prison]

Even if the pastoral care offered by the school was outstanding, there could still be too much distraction to concentrate on schoolwork.

I wasn't even being bad ... just too busy thinking about what was going on.

[Case 6: young person, father awaiting trial]

Schools were also identified as a positive space (even if some aspects were problematic), somewhere to escape from the more challenging aspects of life, where they could maintain a positive sense of identity and achievement, and which could provide them with hope and aspiration. For some, it was the one thing that was right.

I'm, like, the second smartest in my school. [Case 4: child, father in custody]

And then for my Highers, which are really important, like get you into uni grades, I got two As and three Bs.... I'm applying for medicine this year. [Case

1: young person, mother released from prison]

Parents felt that training and awareness-raising was needed among school staff and even whole communities in order to ameliorate the experience for children at school. They expected school staff to be proactive in seeking to support students who might not express need explicitly. A variety of staff members might be chosen by children who divulge their concerns, so training needed to be school-wide in nature. Schools could also be tied in more effectively to multi-agency networks so that families could have school support as part of a broader network of support.

\section{Humanising the Criminal Justice System}

Families felt vulnerable and reported experiences of stigma, bullying and victimisation by criminal justice agencies and the community. Some families had a long history of contact with the police due to a series of previous accusations or repeated victimisation experiences. When contact was frequent and on-going, families reported a sense that they were being unfairly targeted or were trapped in a neverending cycle.

It just felt as if it kept repeating itself. As soon as you start to get better, the police would be there at your back door again. The police were not hearing our side of the story. I felt intimidated, as if I'd done something wrong. [Case 3: young person, father in custody]

It's pure embarrassing. I hate it. I'm out with my work, I'm training to be a youth worker, and the wee ones are looking across, and I'm supposed to be a role model, and I'm getting shoes and that took off me (during a police search).

[Case 8: young person, mother released from prison] 
Children who witnessed the arrest of their parent(s) reported the experience to be shocking and frightening, and concerns were raised about lack of communication and childcare arrangements whilst parents were detained in police custody.

I hate going to sleep now, because as soon as you hear a noise you think that somebody's going to batter your door in. [Case 8: young person, mother released from prison]

In the case of one young person, the police had attended a series of domestic abuse incidents between her mother and partners. She felt that the police had dismissed the incidents as trivial and had failed to recognise the seriousness of the situation.

They'd been all like 'Oh, it's just a domestic abuse thing'. They were just like 'Oh, I remember coming out to this house before'. [Case 1: child, mother released from prison]

Other families also expressed opinions that the police had failed to connect information or had neglected to make appropriate referrals to other agencies.

They don't [view] the whole picture. They never passed them on for putting social work in to see if there is any support they need. They never notified the school of any of this, and yet the community cop has a meeting here once a month. [Case 2: mother, father in custody]

These families commonly reported a lack of trust in the police.

I don't trust them. I wouldn't phone them if I did have a problem. But obviously there's stuff that needs to be done. You can't just ignore it. Say if the window gets smashed or the motor gets smashed up, you have to phone the police to report it so it gets fixed. But I don't see the point in phoning them any more.

[Case 3: young person, father in custody]

In other families, parents had been arrested for the first time, and this was accompanied by feelings of shock and disbelief. Some children and young people were able to recall one or both of their parents being arrested, but others had more blurred recollections, and there was some suggestion that they might have blocked the experience from their memory.

I remember the day before, the day after, everything else ... all I can remember is looking out the window because I heard people shouting and stuff. When people tell me what happened, I kind of get that, but I just completely forgot about it. [Case 10: young person, father in custody]

Arrests often occurred in the early hours of the morning whilst families were either asleep or getting ready for school and work. The circumstances surrounding the arrest were usually chaotic, and children experienced a combination of panic and worry about what was happening to their parent.

We were up in our beds... and we heard my mum screaming and panicking. I come rushing down the stairs, thinking my mum's fell down the stairs. 'Mum, 
what's wrong? What's wrong?' And I just see these two women and I go, 'Pardon my cheek, but who are you?' And Mum says, 'They're social workers'. I said, 'What's happened? Where's Dad? What's wrong with Dad? Is he hurt?' And then I just panicked. [Case 13: child, father in custody]

[Daughter] relates handcuffs to prison, because you don't go in the street, so she thought I was going to prison. And I kept saying it is fine, don't worry about it, I told you it will be OK' [Case 2: mother, father in custody]

One of the most frequently raised issues was a lack of privacy during prison visits. This was partly due to the close proximity of other prisoners and their families, but also a sense that they were being observed closely by the officers. The visiting environment was tense, and communication between prisoners and their families stunted. Families also expressed dissatisfaction with rules limiting physical contact.

The visits are just horrible, because they're so cramped and you don't want to talk about things. When I went through that miscarriage, my dad was absolutely distraught he was not here. And on that visit, I felt as if they were extra close. I do believe when something goes wrong, or something happens, you should have a wee private room just to go in. You should have space. [Case 12: young person, father in custody]

There's got to be twenty screws [prison officers] to a room around them, staring at them, making sure you're not touching. But how's that right? Because my wee niece going to visit my mum, which is her granny, and she's not even allowed to touch my mum. She's allowed to get a hug and then she gets a hug when she leaves. That's not right. [Case 9: young person mother in custody] I think, especially enhanced prisoners, if they're trusted enough to be let out in the community and whatever, why are they not trusted enough to have peace and quiet at a visit with their families? [Case 10: mother, father in custody]

Although some prisons provided play areas for younger children, these were not accessible to imprisoned parents on 'normal' visits. Opportunity for interaction between parent and child was limited. There was also some suggestion that under$16 \mathrm{~s}$ were being searched inappropriately.

You go into a visit room and just sit. I cannot move with her, so it was a bit awkward because she was just coming up for three. She wants to run about and go and play with stuff, and she's asking me to go with her, but I can't. [Case 7: father released from custody]

She [daughter] stood embarrassed. Her eyes were all filling up. She was red. It wouldn't take much to put a wee screen around. If somebody's patting you down like that, your kids know you're not in the airport. You're in a prison. It's degrading. It's embarrassing. [Case 11: mother, father in custody]

They know I am not old enough to be searched, but they [say] 'Open your mouth and empty your pockets'. It's a bit shit, but we have to do it. [Case 11: child, father in custody]

Relationality, as a key perspective of the symbiotic harms framework, acknowledges the harms of families' relationships with the prison. This research broadens 
this understanding to highlight families' experiences with the wider criminal justice system and the harms that flow from engagement with these agencies, the police, courts, probation and prison, and calls for humanising the criminal justice system in order to facilitate more positive outcomes for those in prison and their families. The mutuality of the harms of interaction with state agencies was emphasised. Not only were children impacted by their own engagement with agencies, but they were also impacted by witnessing or experiencing the relationship of their family member in custody with state agencies. For example, children were sometimes traumatised watching the brutality with which their parent was arrested or the manner in which they were surveyed within the prison. As noted by Condry and Minson (2020), symbiotic harms are characterised by mutuality: they can be mitigated or worsened through relationships, in that those in prison and their families are affected by what happens to each other.

\section{Discussion and Conclusion}

This study addressed gaps in existing knowledge to explore the impact of having a parent involved in five different stages of the criminal justice system: arrest, court, probation, prison and resettlement. As a key perspective in the symbiotic harms approach, along with exploring the significant challenges experienced by children with a parent involved in the criminal justice system, this study has equally brought attention to the capacity, resilience and resistance of families and children with a parent in prison as they negotiate and make sense of their situation.

\section{Sources of Support}

The disruption of kin relationships was a key challenge for families and children of those in prison, having a significant impact on participants' sense of personhood. Children drew support from a range of sources, however, the absence of help for those who supported the children was a major concern for families. Recognising the significance of wider relationships, participants identified three sources of solutions. Supporting the notion of symbiotic harms, schools were seen both as a place of stress and threat, and as a haven and an opportunity for a chosen adult to exert a lasting positive impact. Resilience was promoted, and vulnerability and isolation were overcome if the right member of staff could be identified and they responded positively with sensitivity. Children found an outlet and a means to achieve something positive in their life despite all other stressors. Schools need to move proactively to identify need, avoiding assumptions of coping when a child is hiding in isolation, and adopting a sensitive approach to outbursts or periods of particular distress. Routine consideration should be given to the possibility of exposure to adverse childhood experiences, both directly through discussion with parents and indirectly when observing and assessing behaviour and responses. Given the scale of the problem, the Police (as Campus Cops undertaking community-orientated preventive work in schools) could also emphasise that many children face additional challenges that 
may not be known to other students, that having a parent involved in the criminal justice system is common, but that this means that the children deserve additional support and understanding from their peers.

Although families were distrustful of statutory services (and there were examples of individuals excelling in understanding and support), they had found enormous value in non-statutory, independent and Third Sector support. They sought more emphasis on central funding for support through these avenues. The third source of support was held to be a largely untapped but potentially effective resource. Parents sought more focus on the development and central assistance of peer-support groups: parent-to-parent and young people-led groups. A means for affected families to be put in touch with such groups was needed.

Supporting the symbiotic harms approach, the findings of this research clearly highlighted that families and children of those in prison are not a homogenous group, and the complexity and variation in the ways children, young people and their families relate to state agencies was identified. The findings reflected the literature to show that schools could be a valuable place for support (Jones \& Wainaina-Wozna, 2013) but also a source of stigma (Wildeman et al., 2017). Agencies supposedly there to protect families (police, social work) were instead viewed and experienced as a threat. Contact with the justice system not only changed structures, roles, and relationships within families, but also relationships and experiences with the state (Tilley-Riley, 2016). Practitioners and managers recognised this lack of trust and recognised the need to address it but struggled to identify clear solutions.

\section{Humanising the Experience}

The most emphatic message from the young people was the need to humanise their experience - from arrest of a parent to the years after their release. Recognising the mutuality of punishment, it became clear that those in prison and their families are affected by what happens to each other. They felt themselves to be victimised by the authorities and by the community, and this led to immense disruption in their lives: the loss of their childhood. They sought more child-friendly prison visiting, with the ability to engage in physical contact with the parent and to undertake meaningful activity together. They wanted police officers, prison officers and others to acknowledge their innocence and their needs as a child, and they recognised the need for a more structured and supportive transition during adolescence. Their comments also suggest the need for community-based interventions to educate others about the impact on children of victimisation.

\section{Promoting Resilience}

Arditti and Johnson (2020) note the development of an agenda to move beyond consideration of the effects and problems of parental imprisonment to focus on the possibilities of a resilience-based approach. Indeed, this is consistent with the symbiotic harms approach, which recognises that families are not passive recipients of the harms of familial imprisonment, instead constantly negotiating the process of 
punishment harms. Within this study it was important to establish at first hand the challenges faced by children and young people who had experienced the involvement of a parent in the criminal justice system, to understand which issues they experienced as being most problematic, and then to gain additional insights from parents and professionals. Starting with the children's personal perspectives, then situating their narrative in the wider context of their family and supportive services ensured that the authentic voice of the young people was prioritised.

Key features of the building and maintenance of resilience were identified. As identified by Condry and Minson (2020, p.10) and the relational perspective of the symbiotic harms approach, the lives of those in prison and their families are "embedded at a material, emotional, and metaphorical level, and do not simply end when an individual is removed from the family home'. Young people sought to sustain a meaningful bond with their parent in prison, but this element was hindered through the limitations of prison visiting. The substitution of a different, positively-focused adult (often a teacher) was found to reinforce resilience when this was available, but more action was needed in schools to maximise the wider potential for a supportive environment. The foundation of strength in the non-incarcerated parent was often damaged by the lack of support for them in their supportive role of their own children. Children and young people would find instead that they became carers for their parents. Despite the problems, the young people could recognise some of their own strengths and abilities, harbouring ambitions to develop a professional career, and looking beyond the current situation to better times ahead. They sought only relatively small changes from professionals and services, and community-based interventions to educate others about the impact on children of victimisation to allow them to pursue their own coping strategies.

Author Contributions TL secured ethics approval, collected and analysed data, managed the project, drafted the manuscript, revised it critically for important intellectual content, and approved the final version.

KL collected and analysed data, revised the manuscript critically for important intellectual content, and approved the final version.

NL managed data collection and local partnerships, revised the manuscript critically for important intellectual content, and approved the final version.

BN secured additional ethics approval, collected data, reviewed the manuscript critically for important intellectual content, and approved the final version.

BR collected and analysed data.

KS collected and analysed data, reviewed the manuscript critically for important intellectual content, and approved the final version.

LG conceived the project, supported participant recruitment, reviewed the manuscript critically for important intellectual content, and approved the final version.

Improving outcomes for children affected by parental involvement with the criminal justice system in Scotland.

\section{Declarations}

This research was funded by NHS Greater Glasgow and Clyde. Ref: GGC0472. This paper is in part based on the unpublished research report written by the authors submitted to NHS Greater Glasgow and Clyde.

Conflict of Interests The authors declare no conflict of interests but LG works for the commissioner of the study. 
Anonymised data may be requested from LG, subject to use only for non-commercial purposes.

Code Availability Not applicable.

Informed Consent Research ethics approval was secured from the University of Salford Ref: HSR161722. Informed consent was secured from all participants, including children. This included consent to publish anonymised and pooled contributions by participants.

Open Access This article is licensed under a Creative Commons Attribution 4.0 International License, which permits use, sharing, adaptation, distribution and reproduction in any medium or format, as long as you give appropriate credit to the original author(s) and the source, provide a link to the Creative Commons licence, and indicate if changes were made. The images or other third party material in this article are included in the article's Creative Commons licence, unless indicated otherwise in a credit line to the material. If material is not included in the article's Creative Commons licence and your intended use is not permitted by statutory regulation or exceeds the permitted use, you will need to obtain permission directly from the copyright holder. To view a copy of this licence, visit http://creativecommons.org/licen ses/by/4.0/.

\section{References}

Arditti, J. (2018). Parental incarceration and family inequality in the United States. In. R. Condry, \& P. Scharff Smith (Eds.), Prisons, punishment, and the family: towards a new sociology of punishment? (Chapter 3). Oxford: Oxford University Press. Retrieved March 31, 2021, from https://oxford.unive rsitypressscholarship.com/view/10.1093/oso/9780198810087.001.0001/oso-9780198810087-chapt er-3

Arditti, J. A., \& Johnson, E. I. (2020). A family resilience agenda for understanding and responding to parental incarceration. American Psychologist. https://doi.org/10.1037/amp0000687

Arditti, J. A., Lambert-Shute, J., \& Joest, K. (2003). Saturday morning at the jail: Implications of incarceration for families and children. Family Relations, 52(3), 194-204. https://doi.org/10.1111/j.17413729.2003.00195.x

Ayre, L., Philbrick, K., Reiss, M. (2006). Children of imprisoned parents: European perspectives on good practice. Children of Prisoners Europe. Retrieved March 31, 2021, from https://childrenof prisoners.eu/wp-content/uploads/2016/01/Children-of-Imprisoned-Parents-European-Perspectiveson-Good-Practice.pdf

Bartlett, T., Flynn, C., Trotter, C. (2018). “They didn't even let me say goodbye”: A study of imprisoned primary carer fathers' care planning for children at the point of arrest in Victoria, Australia. Child Care in Practice, 24(2). https://doi-org.salford.idm.oclc.org/10.1080/13575279.2017.1420035

Beresford, S., Loucks, N., \& Raikes, B. (2020). The health impact on children affected by parental imprisonment. BMJ Paediatrics Open, 4, e000275. https://doi.org/10.1136/bmjpo-2018-000275

Booth, N. (2020). Maintaining family ties: How family practices are renegotiated to promote motherchild contact. In K. Lockwood (Ed.), Mothering from the inside: Research on mothering and imprisonment (pp. 31-48). Emerald Publishing.

Boswell, G. (2018). Imprisoned fathers and their children: A reflection on two decades of research. Child Care in Practice, 24(2), 212-224. https://doi.org/10.1080/13575279.2017.1420037

Clarke, A. (2004). The mosaic approach and research with young children. In V. Lewis, V. Kellet, C. Robinson, S. Fraser, \& S. Ding (Eds.), The reality of research with children and young people (pp. 142-157). The Open University.

Condry, R., \& Minson, S. (2020). Conceptualizing the effects of imprisonment on families: Collateral consequences, secondary punishment, or symbiotic harms? Theoretical Criminology. https://doi. org/10.1177/1362480619897078

Council of Europe. (2018). Recommendation CM/Rec(2018)5 of the Committee of Ministers to member States concerning children with imprisoned parents. Retrieved March 31, 2021, from https://rm.coe. int/cm-recommendation-2018-5-concerning-children-with-imprisoned-parents-e/16807b3438. 
Crawford, J. (2003). Alternative sentencing necessary for female inmates with children. Corrections Today, 65(3), 8-10.

Cunningham, A. (2001). Forgotten families - the impacts of imprisonment. Family Matters, 59, 35-38.

Dallaire, D. H., \& Wilson, L. C. (2010). The relation of exposure to parental criminal activity, arrest, and sentencing to children's maladjustment. Journal of Child and Family Studies, 19, 404-418. https:// doi.org/10.1007/s10826-009-9311-9

Dallaire, H. D., Ciccone, A., \& Wilson, L. C. (2010). Teachers' experiences with and expectations of children with incarcerated parents. Journal of Applied Developmental Psychology, 31, 281-290. https://doi.org/10.1016/j.appdev.2010.04.001

Dickie, D. (2013). The financial impact of imprisonment on families. Families Outside. Retrieved March 31, 2021, from https:/www.familiesoutside.org.uk/content/uploads/2013/10/financial-impact-impri sonment-families.pdf.

Dodds, S. (2016). Health and early years, children and young people: a GCPH synthesis. Glasgow Centre for Population Health. Retrieved March 31, 2021, from https://www.gcph.co.uk/assets/0000/ 5754/Early_years_synthesis.pdf

Epstein, R. (2011). Mothers in prison: The rights of the child. Criminal Justice Matters, 86(1), 12-13. https://doi.org/10.1080/09627251.2011.646183

Farmer, L. (2017). The importance of strengthening prisoners' family ties to prevent reoffending and reduce intergenerational crime. Available at: https://assets.publishing.service.gov. uk/government/ uploads/system/uploads/attachment_data/file/642244/farmerreview-report.pdf.

Flynn, C., Naylor, B., \& Arias, P. (2015). Responding to the needs of children of parents arrested in Victoria, Australia. The role of the adult criminal justice system. Australian \& New Zealand Journal of Criminology, 49(3), 351-369. https://doi.org/10.1177/0004865815585390

Gifford, E. J., Eldred, L. M., Sloan, F. A., \& Evans, K. E. (2016). Parental criminal justice involvement and children's involvement with child protective services: Do adult drug treatment courts prevent child maltreatment? Substance Use \& Misuse, 51(2), 179-192. https://doi.org/10.3109/10826084. 2015.1089906

Gillies, M., Knifton, L., Dougall, R. (2012). Prison health in NHS Greater Glasgow \& Clyde; a health needs assessment. NHS Greater Glasgow \& Clyde. Retrieved March 31, 2021, from https://www. nhsggc.org.uk/media/258972/equalities_prison_health_in_nhsggc_2012.pdf.

Glasgow Community Justice Authority. (2013). Annual Report 2012-2013. Retrieved March 31, 2021, from http://www.glasgowcja.org.uk/CHttpHandler.ashx?id=18722\&p=0.

Glasgow Community Justice Authority. (2014). Annual Report 2013-2014. Retrieved March 31, 2021, from https://www.glasgowcja.org.uk/CHttpHandler.ashx?id $=26412 \& \mathrm{p}=0$.

Glover, J. (2009). Every night you cry: the realities of having a parent in prison. Barnardo's. Retrieved March 31, 2021, from https://www.bl.uk/collection-items/every-night-you-cry-the-reali ties-of-having-a-parent-in-prison.

Halsey, M. (2018). 'Everyone is in damage control'. In. R. Condry, P. Scharff Smith. (Eds.) Prisons, punishment, and the family: towards a new sociology of punishment? Chapter 14. Oxford Scholarship Online. Oxford: Oxford University Press. Retrieved March 31, 2021, from https://oxford.university pressscholarship.com/view/10.1093/oso/9780198810087.001.0001/oso-9780198810087-chapter-14.

Hissel, S., Bijleveld, C., Kruttschnitt, C. (2011). The well-being of children of incarcerated mothers. An exploratory study for the Netherlands. European journal of criminology, 8(5); 346-360. $10.1177 \% 2$ F1477370811415755.

HM Inspectorate of Prisons. (2016) Annual Report 2015-16. Retrieved September 13, 2021, from https:// www.justiceinspectorates.gov.uk/hmiprisons/wp-content/uploads/sites/4/2016/07/HMIP-AR_201516_web.pdf.

Houchin, R. (2005). Social exclusion and imprisonment in Scotland. Glasgow Caledonian University. Retrieved March 31, 2021, from https://www.scotpho.org.uk/media/1847/social-exclusion-andimprisonment-in-scotland-2005.pdf

Hutton, M., \& Moran, D. (Eds.). (2019). The Palgrave handbook of prison and the family. Palgrave MacMillan.

Jardine, C. (2018). Constructing and maintaining family in the context of imprisonment. British Journal of Criminology, 58(1), 114-131. https://doi.org/10.1093/bjc/azx005

Jones, A.D., \& Wainaina-Wozna, A.E. (Eds.), (2013) Children of prisoners. Interventions and mitigations to strengthen mental health. University of Huddersfield. Retrieved March 31, 2021, from https:// childrenofprisoners.eu/wp-content/uploads/2013/12/COPINGFinal.pdf. 
Kelly-Irving, M., Lepage, B., Dedieu, D., et al. (2013). Adverse childhood experiences and premature allcause mortality. European Journal of Epidemiology, 28(9), 721-734.

Kincaid, S., Roberts, M., \& Kane, E. (2019). Children of prisoners: fixing a broken system. Crest Advisory and University of Nottingham. Retrieved on 13 September 2021 from: https://www.nicco.org. uk/userfiles/downloads/5c90a6395f6d8-children-of-prisoners-full-report-web-version.pdf.

King, D. (2002). Parents, children and prison: effects of parental imprisonment on children. Dublin Institute of Technology. Retrieved March 31, 2021, from https://arrow.tudublin.ie/cgi/viewcontent.cgi? article $=1011 \&$ context $=$ cserrep.

Lanskey, C., Lösel, F., Markson, L., \& Souza, K. (2019). Prisoners' families' research: Developments, debates and directions. In M. Hutton \& D. Moran (Eds.), The Palgrave handbook of prison and the family. Palgrave MacMillan.

Lee, H., Wildeman, C., Wang, E. A., Matusko, N., \& Jackson, J. S. (2014). A heavy burden: The cardiovascular health consequences of having a family member incarcerated. American Journal of Public Health, 104(3), 421-427. https://doi.org/10.2105/AJPH.2013.301504

Livesley, J., \& Long, T. (2012). Children's experiences as hospital in-patients: voice, competence and work. Messages for nursing from a critical ethnographic study. International Journal of Nursing Studies, 50(10), 1242-1303. https://doi.org/10.1016/j.ijnurstu.2012.12.005.

Lockwood, K., Long, T., Loucks, N., Raikes, B., Sharratt, K. (2021). A double-edged sword: children's experiences of visiting a parent in prison in Scotland. Probation Journal. https://doi.org/10.1177/ 02645505211025592 .

Lockwood, K., Raikes, B. (2016). A difficult disclosure: the dilemmas faced by families affected by parental imprisonment regarding what information to share. In R. Reeves (Ed.), Experiencing imprisonment: research on the experience of living and working in carceral institutions (pp. 230247). London: Routledge.

Long, T. (2007). What are the ethical issues in research? In T. Long \& M. Johnson (Eds.), Research ethics in the real world: issues for health and social care (pp. 47-62). Edinburgh: Elsevier.

Long, T., Lockwood, K., Raikes, B., Sharratt, K., Loucks, N., Nugent, B. (2019). Constructive Connections: building resilience in families affected by the criminal justice system. University of Salford, University of Huddersfield, Families Outside. http://usir.salford.ac.uk/id/eprint/56837.

Lösel, F., Pugh, G., Markson, L., Souza, K.A., Lanskey, C. (2012). Risk and protective factors as predictors of fathers' resettlement and families' adjustment. University of Cambridge. Retrieved March 31, 2021, from https://www.fair.crim.cam.ac.uk/files/ormistonreport.

Loucks, N. (2012). Prisons: where doesn't the community come in? Prison Service Journal 204, $42-50$.

Măirean, C., Turliuc, M., Christmann, K. (2012). Risk and resilience in children of prisoners: a research review. Scientific Annals of the Alexandru Ioan Cuza University. Sociology and Social Work Section (Analele Ştiinţifice ale Universităţii "Alexandru Ioan Cuza" din Iaşi. Sociologie şi Asistenţă Socială) 5(2), 5376. Retrieved March 31, 2021, from http://eprints.hud.ac.uk/id/eprint/ $16480 /$

Manby, M. (2015). Exploring the emotional impact of parental imprisonment on children through children's, parents' and carers' accounts. Unpublished Doctoral Thesis. University of Huddersfield. Retrieved March 31, 2021, from http://eprints.hud.ac.uk/id/eprint/24268/1/Final_thesis_-_ MANBY.pdf.

McCarthy, D., \& Adams, M. (2017). Prison visitation as human 'right' or earned 'privilege'? The differing tales of England/Wales and Scotland. Journal of Social Welfare and Family Law, 39(4), 403-416. https://doi.org/10.1080/09649069.2017.1390292

McGillivray, C. (2016). Rendering them visible. A review of progress towards increasing awareness and support of prisoners' families. Families Outside. Retrieved March 31, 2021, from https:// www.familiesoutside.org.uk/rendering-visible-3-2/.

McGinley, M., \& Jones, C. (2018). Growing up with parental imprisonment: children's experiences of managing stigma, secrecy and shame. Practice, 30(5), 341-357. https://doi.org/10.1080/09503 153.2018.1450497

Minson, S. (2021). Maternal sentencing \& the rights of the child. Palgrave MacMillan. https://doi.org/ 10.1007/978-3-030-32738-5

Murray, J. (2007). The cycle of punishment: Social exclusion of prisoners and their children. Criminology and Criminal Justice, 7(1), 55-81. https://doi.org/10.1177/2F1748895807072476 
Murray, J., Farrington, D. P., Sekol, I., \& Olsen, R. F. (2009). Effects of parental imprisonment on child antisocial behaviour and mental health: A systematic review. Campbell Systematic Reviews, 4, 1-105. https://doi.org/10.4073/csr.2009.4

Murray, J., Loeber, D., \& Pardini, D. (2012). Parental involvement in the criminal justice system and the development of youth theft, marijuana use, depression and poor academic performance. Criminology, 50(1), 255. https://doi.org/10.1111/j.1745-9125.2011.00257.x

Parke, R., \& Clarke-Stewart, K.A. (2002). Effects of parental incarceration on young children. Washington DC: US Department of Health and Human Services. Retrieved March 31, 2021, from https://www.ncjrs.gov/App/Publications/abstract.aspx?ID=202994.

Phillips, S., \& Detlaff, A. (2009). More than parents in prison: The broader overlap between the criminal justice and child welfare systems. Journal of Public Child Welfare, 3(1), 3-22. https://doi. org/10.1080/15548730802690718

Phillips, S. D., \& Zhao, J. (2010). The relationship between witnessing arrests and elevated symptoms of posttraumatic stress: Findings from a national study of children involved in the child welfare system. Children and Youth Services Review, 32(1), 1246-1254. https://doi.org/10.1016/j.child youth.2010.04.015

Phillips, S. D., Burns, B. J., Wagner, H. R., Kramer, T. L., \& Robbin, J. M. (2002). Parental incarceration among adolescents receiving mental health services. Journal of Child and Family Studies, 11(4), 385-399. https://doi.org/10.1023/A:1020975106679

Poehlmann, J. (2005). Representations of attachment relationships in children of incarcerated mothers. Child Development, 76(3), 679-696. https://doi.org/10.2307/3696459

Prison Reform Trust. (2013). Prison: the facts. Prison Reform Trust. Retrieved March 31, 2021, from http://www.prisonreformtrust.org.uk/Portals/0/Documents/Prisonthefacts.pdf

Rieder, J. K., Goshin, L. S., Sissoko, D. R. G., Kleshchova, O., \& Weierich, M. R. (2019). Salivary biomarkers of parenting stress in mothers under community criminal justice supervision. Nurse Researcher, 68(1), 48-56. https://doi.org/10.1097/NNR.0000000000000323

Ritchie, J., \& Lewis, J. (2003). Qualitative research practice: A guide for social science students and researchers. Sage.

Scharff-Smith, P., \& Gampell, L. (2011). Children of imprisoned parents. The Danish Institute for Human Rights, European Network for Children of Imprisoned Parents, University of Ulster and Bambinisenzasbarre. Retrieved March 31, 2021, from https://childrenofprisoners.eu/wp-content/uploads/2014/ 01/Full-report-Children-of-Imprisoned-parents.pdf.

Scottish Centre for Crime and Justice Research. (2019). Scotland's prison population. Retrieved September 13, 2021, from https://www.sccjr.ac.uk/wpcontent/uploads/2019/10/7-Scotlands-prison-popul ation.pdf.

Scottish Government. (2012). A Guide to Getting It Right for Every Child. Edinburgh: Scottish Government. Retrieved March 31, 2021, from https://www.gov.scot/policies/girfec/

Scottish Government. (2017). Justice in Scotland: vision and priorities. Edinburgh: Scottish Government. Retrieved March 31, 2021, from https://www.gov.scot/publications/justice-scotland-vision-prior ities/.

Scottish Government Justice Analytical Services. (2012). Freedom of Information Request from Dr Chris Holligan, 26 January 2012.

Smith, J., \& Firth, J. (2011). Qualitative data analysis: The framework approach. Nurse Researcher, 18(2), 52-62. https://doi.org/10.7748/nr2011.01.18.2.52.c8284

Smith, R., Grimshaw, R., Romeo, R., Knapp, M. (2007). Poverty and disadvantage among prisoners' families. Joseph Rowntree Foundation. Retrieved March 31, 2021, from https:/www.jrf.org.uk/ report/poverty-and-disadvantage-among-prisoners-families.

Steinhoff, R., \& Berman, A. H. (2012). Children's experiences of having a parent in prison: 'We look at the moon and then we feel close to each other'. Sociology and Social Work, 5(2), 77-96.

Tilley-Riley, J. (2016). Collateral Damage. An inquiry into the impact of witnessing a home raid by the police, on the children and the siblings of offenders in England. London: Clore Social Leadership. Retrieved March 31, 2021, from https://www.nicco.org.uk/userfiles/downloads/845\%20-\%20Col lateral\%20Damage.pdf.

Turney, K. (2018). Adverse childhood experiences among children of incarcerated parents. Children and Youth Services Review, 89(C), 218-225. https://doi.org/10.1016/j.childyouth.2018.04.033

UNICEF. (1989). United Nations Convention on the Rights of the Child. UNICEF. Retrieved March 31, 2021, from https://www.unicef.org.uk/what-we-do/un-convention-child-rights/. 
United Nations. (2021). Artificial intelligence and privacy, and children's privacy. Report of the Special Rapporteur on the right to privacy. Human rights Council A/HRC/46/37. Retrieved March 31, 2021, from https://undocs.org/A/HRC/46/37.

Whitehead, M., \& Dahlgren, G. (2007). Concepts and principles for tackling social inequalities in Health. World Health Organisation. Retrieved March 31, 2021, from https://www.euro.who.int/_ data/assets/pdf_file/0010/74737/E89383.pdf.

Wildeman, C., Scardamalia, K., Walsh, E. G., O’Brien, R. L., \& Brew, B. (2017). Paternal incarceration and teachers' expectations of students. Socius, 3, 1-14. https://doi.org/10.1177/2378023117726610

Woodall, J., \& Kinsella, K. (2017). Playwork in prison as a mechanism to support family health and wellbeing. Health Education Journal, 76(7), 842-852. https://doi.org/10.1177/0017896917716204

Publisher's Note Springer Nature remains neutral with regard to jurisdictional claims in published maps and institutional affiliations.

\section{Authors and Affiliations}

\section{Tony Long ${ }^{1}(1) \cdot$ Kelly Lockwood $^{1}(1) \cdot$ Nancy Loucks $^{2} \oplus \cdot$ Briege Nugent $^{1}(\mathbb{D}$. Ben Raikes $^{3}\left({ }^{\circ} \cdot\right.$ Kathryn Sharratt $^{4}\left([) \cdot\right.$ Louise Gallagher $^{5}(0)$}

Kelly Lockwood

k.lockwood@salford.ac.uk

Nancy Loucks

nancy.loucks@familiesoutside.org.uk

Briege Nugent

briegenugentresearch@gmail.com

Ben Raikes

b.raikes@hud.ac.uk

Kathryn Sharratt

k.sharratt@hud.ac.uk

Louise Gallagher

louise.gallagher@ggc.scot.nhs.uk

1 School of Health \& Society, University of Salford, Salford M6 6PU, UK

2 University of Strathclyde, Families Outside, 17 Gayfield Square, Edinburgh EH1 3NX, UK

3 Division of Social Work, University of Huddersfield, Huddersfield HD1 3DH, UK

4 Department of Behavioural and Social Sciences, University of Huddersfield, Huddersfield HD1 3DH, UK

5 Health Improvement Lead (Community Justice), NHS Greater Glasgow \& Clyde, J B Russell House Gartnavel Royal Hospital Campus, 1055 Great Western Road, Glasgow G12 0XH, UK 